\title{
Palliative radiotherapy for gastric cancer: a systematic review and meta-analysis
}

\author{
Jeremy Tey, ${ }^{1}$, Yu Yang Soon ${ }^{1}$, Wee Yao Koh ${ }^{1}$, Cheng Nang Leong ${ }^{1}$, Bok Ai Choo ${ }^{1}$, \\ Francis Ho${ }^{1}$, Balamurugan Vellayappan ${ }^{1}$, Keith Lim ${ }^{1}$ and Ivan W.K. Tham ${ }^{1}$ \\ ${ }^{1}$ Department of Radiation Oncology, National University Hospital, National Cancer Institute of Singapore, Singapore \\ Correspondence to: Jeremy Tey, email: Jeremy_tey@nuhs.edu.sg \\ Keywords: radiotherapy, gastric cancer, palliation, bleeding, pain \\ Received: December 01, $2016 \quad$ Accepted: February 07, $2017 \quad$ Published: February 20, 2017 \\ Copyright: Tey et al. This is an open-access article distributed under the terms of the Creative Commons Attribution License (CC-BY), which \\ permits unrestricted use, distribution, and reproduction in any medium, provided the original author and source are credited.
}

\section{ABSTRACT}

Background/Purpose: To review the efficacy and toxicity of palliative radiotherapy (RT) for symptomatic locally advanced gastric cancer (GC) and to determine the optimal RT schedule for symptom palliation.

Methods: We searched MEDLINE and CENTRAL for eligible studies published from 1995 to 2015 . Outcomes of interest were relief of bleeding, pain and obstruction.

Results: Seven non-comparative observational studies were included. There were large variations in RT dose and fractionation. The pooled overall response rates for bleeding, pain and obstruction symptoms were $74 \%, 67 \%$ and $68 \%$ respectively. There was no difference in response rate of bleeding between regimens with high biological equivalent dose (BED) of $\geq 39 \mathrm{~Gy}$ versus regimens with low BED<39Gy regimens ( $p$ value $=0.39$ ). Grade 3 to 4 toxicities occurred in up to $15 \%$ of patients for patients treated with RT alone and up to $\mathbf{2 5 \%}$ of patients treated with chemoradiotherapy. Health-related quality of life (HRQL) outcomes were not reported.

Conclusion: More than two-thirds of patients receiving RT would have a clinical benefit. Low BED regimens appear to be adequate for symptom palliation. Toxicity rates appear acceptable for patients treated with RT alone. The optimal dose fractionation regimen for symptom palliation remains unclear. Prospective studies to determine the effects of palliative gastric RT on HRQL outcomes are warranted.

\section{INTRODUCTION}

Local tumour progression is often a cause of the presenting symptoms in patients with recurrent and locally advanced primary gastric cancers. Even in GC patients that do not initially present with local symptoms, they eventually may require intervention for progressive local symptoms while on palliative chemotherapy.

Common local symptoms that patients present with or develop include obstruction, bleeding or pain. The intervention options for relieving local symptoms include palliative radiotherapy (RT), palliative chemotherapy, gastric bypass surgery, palliative gastrectomy, and endoscopic stenting. The ideal treatment modality should be effective yet having minimal side effects. RT is a non invasive treatment for these local symptoms .[1-4]
Interestingly, there is very scarce literature with regards to the tolerability and the efficacy of RT in palliating the local symptoms. Of debate is also the optimal dose fractionation regimen for effective symptom palliation. In patients with advanced disease, hypofractionated regimens have been increasingly used. Small case series have reported efficacy with hypofractionated regimens, with the added advantage of reduced overall treatment time.[5] Others have suggested that low BED (Biologically Effective Dose) regimens may not be adequate for palliation of obstruction and may be associated with poorer local control compared to higher BED regimens. [6] To date, there have been no published reviews summarizing the benefits of palliative RT for palliation of local symptoms.

The aim of this study is to determine the effectiveness and toxicities of RT in the palliation of local 
GC symptoms. We also sought to determine the optimal dose fractionation regimen by evaluating the different treatment schedules used in symptom palliation.

\section{RESULTS}

\section{Search results}

Figure 1 details the search strategy. We found seven non-comparative observational studies including 291 patients who received palliative RT for relief of local symptoms.[5, 6, 13-16]

\section{Patient characteristics and symptoms}

The characteristics of the seven studies are summarised in Table 1. The studies were published from 2008 to 2015 . All were retrospective reviews. The sample size of the included studies ranged from 15 to 115 patients. Seventy percent $(206 / 291)$ of patients were male. Median age of included patients was 66 years (range 61-78 years). Median follow-up ranged from 2.1 to 35.4 months. All patients underwent gastroscopy which confirmed gastric bleeding.

Majority of patients had adenocarcinoma of the stomach. Two studies included one patient with squamous cell carcinoma $[5,12]$ and one study included one patient with carcinoma with neuroendocrine features of the stomach. [5]

All patients received RT for palliation of local symptoms. Five studies included patients treated with chemoradiotherapy.[ 6, 12-14, 16] All patients in the studies had bleeding as the index symptom. Two studies included patients who presented with pain and obstruction. $[6,15]$ Five studies included patients with both locally advanced and metastatic disease. [5, 6, 13-15] Two studies included patient with metastatic disease only. $[12,16]$

\section{Methological quality of included studies}

The methodological quality of included studies in summarized in figure 3. All studies enrolled a

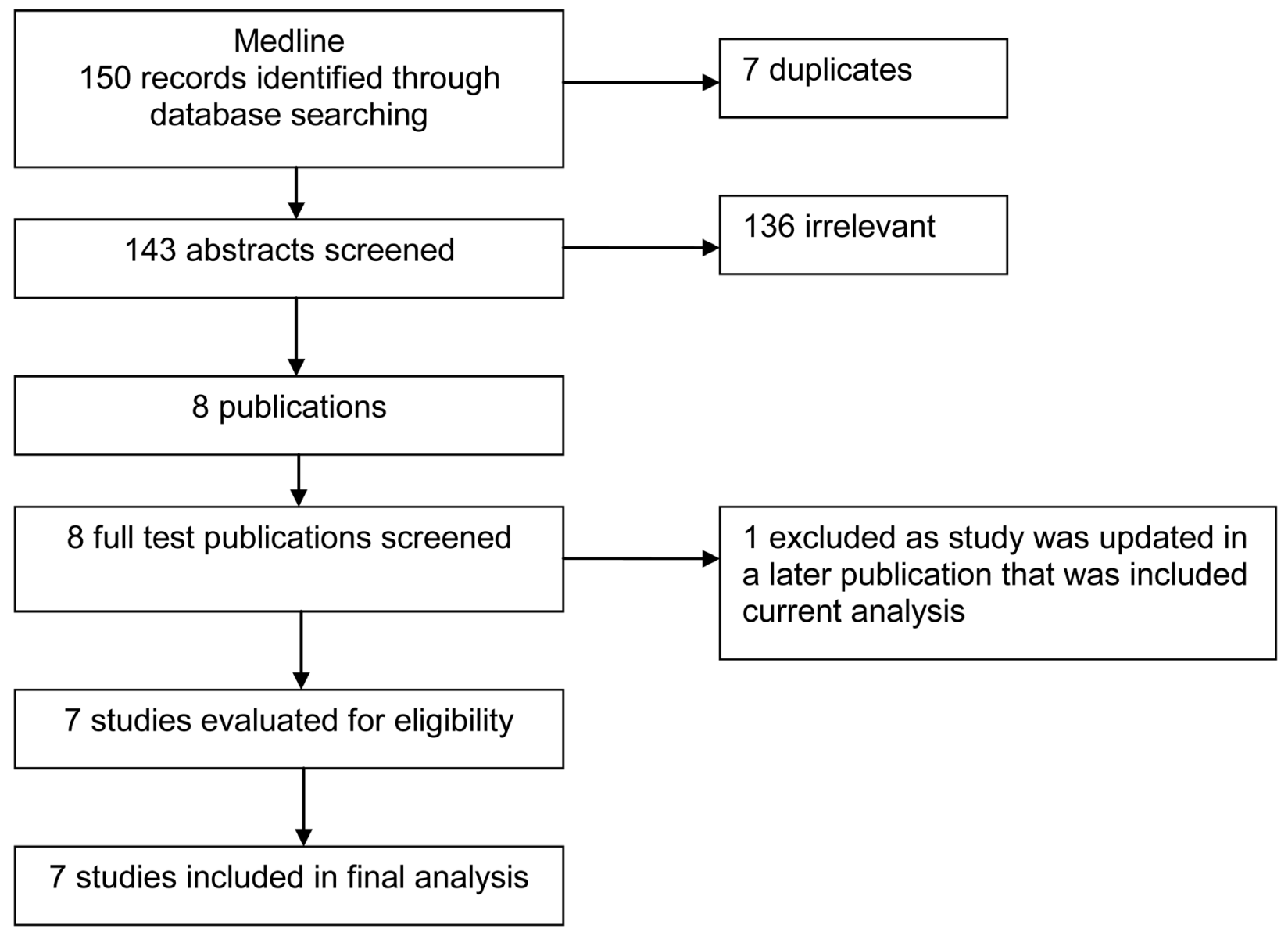

Figure 1: Study flow chart. 
Table 1: Characteristics of studies of palliative radiotherapy for gastric cancer

\begin{tabular}{|c|c|c|c|c|c|c|c|}
\hline \multirow{2}{*}{$\begin{array}{l}\text { Authorl } \\
\text { Year }\end{array}$} & \multirow{2}{*}{$\begin{array}{l}\text { Study design } \\
\text { and treatment } \\
\text { period }\end{array}$} & \multicolumn{2}{|c|}{ Patients } & \multirow{2}{*}{$\begin{array}{l}\text { Computed } \\
\text { Tomography } \\
\text { (CT) planned }\end{array}$} & \multirow{2}{*}{$\begin{array}{c}\text { Radiotherapy } \\
\text { (dose/fraction } \\
\text { size/treatment } \\
\text { period }\end{array}$} & \multirow{2}{*}{ Relevant outcome } & \multirow{2}{*}{$\begin{array}{l}\text { Patient follow- } \\
\text { up (months) }\end{array}$} \\
\hline & & Number & Stage & & & & \\
\hline $\begin{array}{l}\text { Kim MM } \\
2008^{6}\end{array}$ & $\begin{array}{l}\text { Retrospective } \\
1996-2004\end{array}$ & 37 & mixed & NR & $\begin{array}{l}\text { Median 35Gy } \\
(25-36 \mathrm{~Gy})\end{array}$ & $\begin{array}{l}\text { Requirement for further } \\
\text { intervention or presence of } \\
\text { symptoms at follow-up }\end{array}$ & 3.1 \\
\hline $\begin{array}{l}\text { Hashimoto } \\
2009^{12}\end{array}$ & $\begin{array}{l}\text { Retrospective } \\
\text { 1994-2007 }\end{array}$ & 19 & metastatic & Yes & $\begin{array}{l}\text { Median 40Gy } \\
(2-50 \mathrm{~Gy} \text { in } 1.8- \\
3 \mathrm{~Gy} / \mathrm{Fr})\end{array}$ & $\begin{array}{l}\text { Requirement for blood } \\
\text { transfusions after RT }\end{array}$ & NR \\
\hline $\begin{array}{l}\text { Lee JA } \\
2009^{13}\end{array}$ & $\begin{array}{l}\text { Retrospective } \\
\text { 2002-2007 }\end{array}$ & 23 & mixed & No & $30 \mathrm{~Gy} / 10 \mathrm{fr}$ & $\begin{array}{c}\text { Changes in } \mathrm{HB} \text {, number of } \\
\text { transfusions before and after } \\
\text { RT }\end{array}$ & 4 \\
\hline $\begin{array}{l}\text { Asakura } \\
2011^{14}\end{array}$ & $\begin{array}{l}\text { Retrospective } \\
\text { 2002-2007 }\end{array}$ & 30 & mixed & Yes & $30 \mathrm{~Gy} / 10 \mathrm{fr}$ & $\begin{array}{l}\text { Requirement for blood } \\
\text { transfusions after RT }\end{array}$ & $3.5(0.5-19.6)$ \\
\hline $\begin{array}{l}\text { Chaw } \\
2014^{5}\end{array}$ & retrospective & 52 & mixed & NR & $\begin{array}{l}8 \mathrm{~Gy} \text { single fr } \\
20 \mathrm{~Gy} / 5 \mathrm{fr}\end{array}$ & $\begin{array}{c}\text { Changes in } \mathrm{HB} \text {, number of } \\
\text { transfusions before and after } \\
\text { RT }\end{array}$ & NR \\
\hline $\begin{array}{l}\text { Tey } \\
2014^{15}\end{array}$ & $\begin{array}{l}\text { Retrospective } \\
1999-2012\end{array}$ & 115 & mixed & Yes $(93 \%)$ & 8-40Gy & $\begin{array}{c}\text { Symptom response } 3 \text { point } \\
\text { scale }\end{array}$ & 2.8 \\
\hline $\begin{array}{l}\text { Kondoh } \\
2015^{16}\end{array}$ & $\begin{array}{l}\text { Retrospective } \\
2007-2012\end{array}$ & 15 & metastatic & Yes & $\begin{array}{l}\text { Median 30Gy } \\
\text { 30-40Gy/10-20 } \\
\mathrm{fr}\end{array}$ & $\begin{array}{l}\text { Response if : No evidence of } \\
\text { bleeding, increase in HB, no } \\
\text { interventions for bleeding, for } \\
\text { seven days }\end{array}$ & $35.4(0.9-82)$ \\
\hline
\end{tabular}

Table 2: Symptomatic response to palliative radiotherapy for gastric cancer

\begin{tabular}{|c|c|c|c|c|c|c|}
\hline $\begin{array}{l}\text { Authorl } \\
\text { year }\end{array}$ & $\begin{array}{c}\text { Radiotherapy } \\
\text { (dose/fraction } \\
\text { size/treatment } \\
\text { period }\end{array}$ & Index symptom & Response & $\begin{array}{l}\text { Survival } \\
\text { (months) }\end{array}$ & $\begin{array}{l}\text { Duration } \\
\text { (months) }\end{array}$ & BED correlation \\
\hline $\begin{array}{l}\text { Kim MM } \\
2008^{6}\end{array}$ & $\begin{array}{c}\text { Median 35Gy } \\
(25-36 G y), 24 / 37 \\
\text { patients had concurrent } \\
\text { chemotherapy) }\end{array}$ & $\begin{array}{l}\text { Gastric } \\
\text { bleeding, } \\
\text { pain , } \\
\text { obstruction }\end{array}$ & $\begin{array}{c}\text { Bleeding } 70 \%(14 / 20) \text {, pain } \\
86 \%(6 / 7), \text { obstruction } 81 \% \\
(13 / 16)\end{array}$ & 5.2 & $\begin{array}{l}\text { Bleeding (11.4), } \\
\text { pain (NR), } \\
\text { obstruction (6.2) }\end{array}$ & $\begin{array}{l}\text { BED } 41 \text { Gy } 10 \\
\text { conferred better } \\
\text { local control of } \\
\text { symptoms but not } \\
\text { overall survival }\end{array}$ \\
\hline $\begin{array}{l}\text { Hashimoto } \\
2009^{12}\end{array}$ & $\begin{array}{c}\text { Median 40Gy } \\
\text { (2-50Gy in 1.8-3Gy / fr) } \\
\text { (4/19 patients had CRT) }\end{array}$ & $\begin{array}{l}\text { Gastric } \\
\text { bleeding }\end{array}$ & Bleeding $68 \%(13 / 19)$ & 3.4 & 1.5 & $\begin{array}{l}\text { BED } 50 \text { Gy10 } \\
\text { conferred higher } \\
\text { success rate of } \\
\text { haemostasis } \\
\text { compared to those } \\
\text { received BED <50 } \\
\text { Gy10 }\end{array}$ \\
\hline $\begin{array}{l}\text { Lee JA } \\
2009^{13}\end{array}$ & $\begin{array}{c}30 \mathrm{~Gy} / 10 \mathrm{fr} \\
\text { (12/30 patients had } \\
\text { CRT) }\end{array}$ & $\begin{array}{l}\text { Gastric } \\
\text { bleeding }\end{array}$ & Bleeding $91 \%(21 / 23)$ & 4 & 4 & NR \\
\hline $\begin{array}{l}\text { Asakura } \\
2011^{14}\end{array}$ & $\begin{array}{c}30 \mathrm{~Gy} / 10 \mathrm{fr} \\
(12 / 30 \text { patients had } \\
\text { concurrent } \\
\text { chemotherapy) }\end{array}$ & $\begin{array}{c}\text { Gastric } \\
\text { bleeding }\end{array}$ & Bleeding $73 \%(22 / 30)$ & 3.6 & 3.3 & $\begin{array}{l}\text { BED } 39 \text { Gy } 10, \\
\text { conferred a } \\
\text { response rate } \\
\text { comparable to } \\
\text { higher BED ( } 50\end{array}$ \\
\hline $\begin{array}{l}\text { Chaw } \\
2014^{5}\end{array}$ & $\begin{array}{l}8 \mathrm{~Gy} \text { single } \mathrm{fr} \\
20 \mathrm{~Gy} / 5 \mathrm{fr}\end{array}$ & $\begin{array}{l}\text { Gastric } \\
\text { bleeding }\end{array}$ & $\begin{array}{c}\text { Bleeding } 50 \% \text { (22/44, } 8 \\
\text { patients unevaluable) }\end{array}$ & 5.3 & NR & $\begin{array}{l}\text { Gy10 or more) } \\
\text { BED } 28 \text { Gy } 10, \\
\text { conferred a similar } \\
\text { response rate } \\
\text { compared to other } \\
\text { studies }\end{array}$ \\
\hline $\begin{array}{l}\text { Tey } \\
2014^{15}\end{array}$ & 8-40Gy & $\begin{array}{l}\text { Bleeding, } \\
\text { pain, } \\
\text { obstruction }\end{array}$ & $\begin{array}{c}\text { Bleeding } 80.6 \%(83 / 103), \\
\text { pain } 45.5 \%(5 / 11) \\
\text { obstruction } 51.2 \%(9 / 17)\end{array}$ & 2.8 & $\begin{array}{l}\text { Bleeding (3.3), } \\
\text { pain (7.8), } \\
\text { obstruction (3.2) }\end{array}$ & $\begin{array}{l}\text { Trend for poorer } \\
\text { local control for BED } \\
\leq 39 \text { Gy10 }\end{array}$ \\
\hline $\begin{array}{l}\text { Kondoh } \\
2015^{16}\end{array}$ & $\begin{array}{l}\text { Median 30Gy (30-40Gy } \\
\text { in 2-3Gy / fr) } \\
\text { (5/15 patients had CRT) }\end{array}$ & Bleeding & $\begin{array}{c}\text { Bleeding } 80.6 \%(11 / 15- \\
\text { RT: } 7 / 15 \\
\text { CRT: } 4 / 15)\end{array}$ & 2.1 & NR & NR \\
\hline
\end{tabular}

representative sample of patients and defined the outcomes of interest at the start of the studies. Only one study did not provide adequate assessment of outcome. ${ }^{6}$ Kim et al did not provide objective measures of response in their study. All studies allowed for sufficient length of follow up to allow outcomes to arise. Only one study did not clearly account whether all included patients were being followed up. ${ }^{6}$

\section{Radiotherapy dose, fractionation and target and technique}

There were wide variations in dose fractionation regimens between studies. Fraction sizes ranged from 1.8 to $8 \mathrm{~Gy}$ and total doses ranged from $8 \mathrm{~Gy}$ to $50 \mathrm{~Gy}$. The most common dose fraction regimen used was 30Gy 
in $10 \#$. One paper did not state the distribution of dose/ fractionation regimen.[13] 20\% (57/291) of patients were treated with chemoradiotherapy. Four of the studies planned patients using 3 dimensional simulation[12, 14-16], one used 2-dimensional simulation[13] and two studies did not report the planning technique used.[5-6] Target volumes definitions for RT were variable, including the whole stomach or partial stomach, with or without regional lymph nodes. Only one study provided dose constraints used for RT planning. [15] The most common field arrangement was Anterior-Posterior/ PosteriorAnterior fields.

\section{Treatment response}

Response criteria varied across studies for bleeding, pain and obstruction. Different time points were used to assess symptom response. 4 studies evaluated for symptom response one month after $\mathrm{RT}[5,12,14-15]$, one study on

Figure 2-1. Pooled event rate of bleeding response according to BED

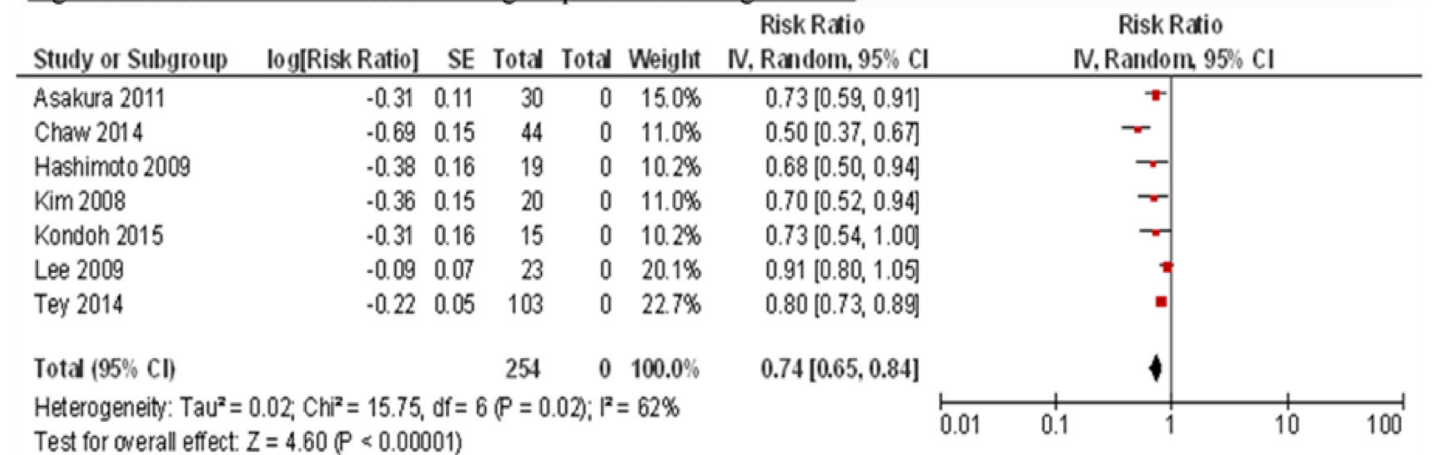

Figure 2-2. Pooled event rate of pain response according to BED

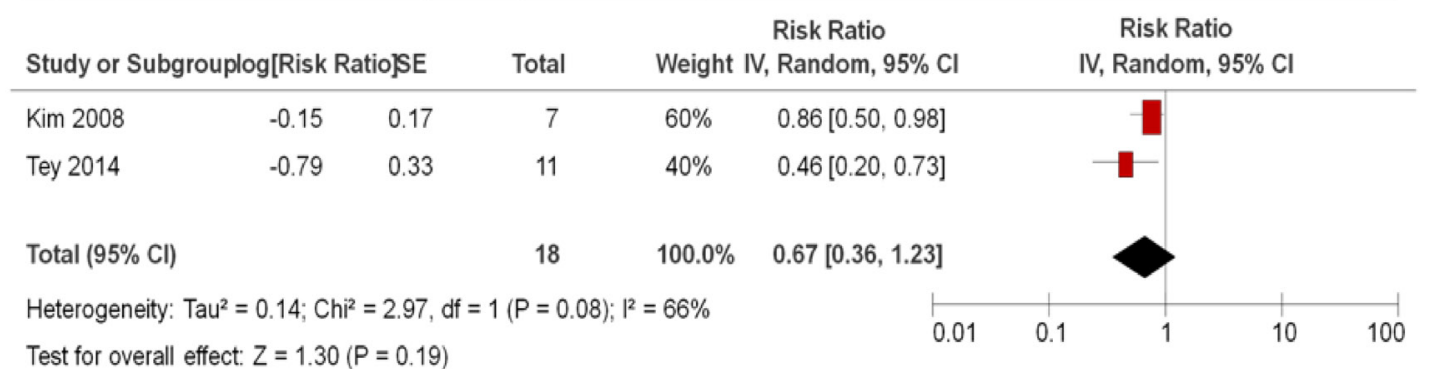

Figure 2-3. Pooled event rate of obstruction response according to BED

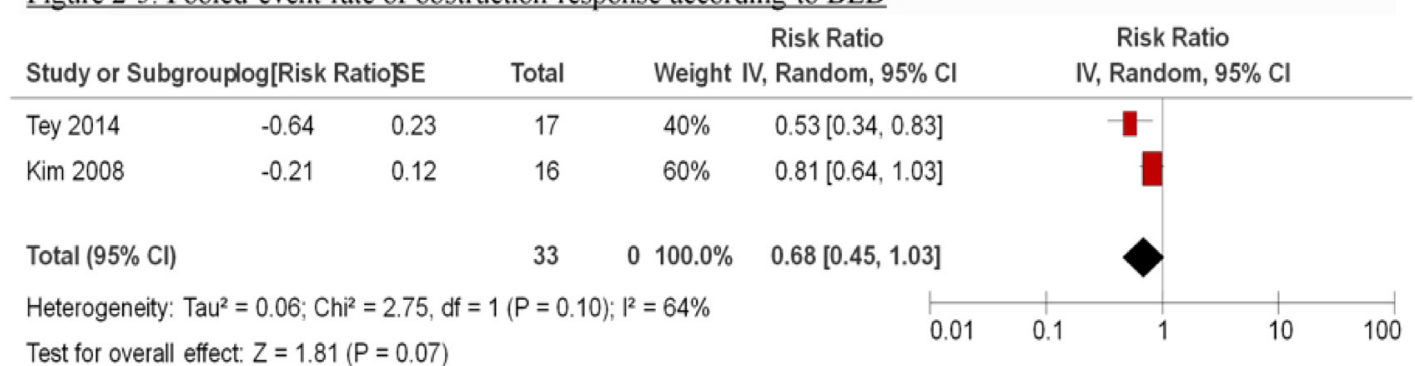

Test for overall effect: $Z=1.81(P=0.07)$

Figure 2-4. Pooled event rate of bleeding response according to BED

\begin{tabular}{|c|c|c|c|c|c|c|c|}
\hline BED & Sample size & Event rate & $95 \%$ CI & $\mathrm{I}^{2}$ & Relative risk & $95 \%$ CI & $\begin{array}{c}\text { Interaction } P \\
\text { value }\end{array}$ \\
\hline$\geq 39 G y$ & 56 & 0.85 & $0.76-0.95$ & $0 \%$ & 1.53 & $1.20-1.95$ & 0.39 \\
\hline$<39 G y$ & 66 & 0.56 & $0.22-1.45$ & $66 \%$ & & & \\
\hline
\end{tabular}

Figure 2: Pooled event responcse according to index symptom. 


\begin{tabular}{|c|c|c|c|c|}
\hline \multirow{2}{*}{$\begin{array}{l}\text { Authorl } \\
\text { year }\end{array}$} & \multicolumn{3}{|c|}{ Acute toxicity (CTC or RTOG) } & \multirow{2}{*}{ Late Toxicity } \\
\hline & $\begin{array}{l}\text { Gastrointestinal } \\
\text { (Grade }>3 \text { ) }\end{array}$ & $\begin{array}{c}\text { Skin/connective } \\
\text { tissue (Grade }>3 \text { ) }\end{array}$ & Others (Grade $>3$ ) & \\
\hline $\begin{array}{l}\text { Kim MM } \\
2008^{6}\end{array}$ & $\begin{array}{c}\text { RT } 15 \%(2 / 13) \\
\text { CRT } 12.5 \%(3 / 24)\end{array}$ & NR & $\begin{array}{c}\text { Neutropenia - } \\
\text { CRT } 8.3 \%(2 / 24)\end{array}$ & NR \\
\hline $\begin{array}{l}\text { Hashimoto } \\
2009^{12}\end{array}$ & $\begin{array}{l}\text { RT } 6.7 \%(1 / 15) \\
\text { CRT 0\% (0/4) }\end{array}$ & NR & $\begin{array}{c}\text { Neutropenia - } \\
\text { RT } 6.7 \%(1 / 15) \\
\text { CRT 25\% (1/4) } \\
\text { Anorexia - } \\
\text { RT } 13.3 \%(2 / 15) \\
\text { CRT 25\% (1/4) }\end{array}$ & NR \\
\hline $\begin{array}{l}\text { Lee JA } \\
2009^{13}\end{array}$ & $0 \%(0 / 23)$ & NR & NR & NR \\
\hline $\begin{array}{l}\text { Asakura } \\
2011^{14}\end{array}$ & $\begin{array}{l}\text { RT } 0 \%(0 / 18) \\
\text { CRT } 0 \%(0 / 12)\end{array}$ & NR & $\begin{array}{l}\text { Neutropenia } \\
\text { Grade } 325 \%(3 / 12) \text { CRT } \\
\text { Grade } 48.3 \%(1 / 12) \text { CRT }\end{array}$ & $\begin{array}{c}\text { GI hemorrhage } \\
\text { Grade } 38.3 \%(1 / 12) \\
\text { CRT }\end{array}$ \\
\hline $\begin{array}{l}\text { Chaw } \\
2014^{5}\end{array}$ & NR & NR & NR & NR \\
\hline $\begin{array}{l}\text { Tey } \\
2014^{15}\end{array}$ & $0.9 \%(1 / 115)$ & Nil & $\begin{array}{c}\text { Gastritis } \\
0.9 \%(1 / 115) \\
\text { Anorexia } \\
0.9 \%(1 / 115)\end{array}$ & Nil \\
\hline $\begin{array}{l}\text { Kondoh } \\
2015^{16}\end{array}$ & NR & Nil & $\begin{array}{l}\text { Neutropenia- } \\
\qquad 20 \%(3 / 15)\end{array}$ & Nil \\
\hline
\end{tabular}

the day of completion of RT[13], one study after 7 days of starting RT[16] and one study 'at follow-up' after RT.[6]

\section{Bleeding}

All 7 studies included a total number of 254 patients who presented with gastric bleeding. Varying definitions were used to define treatment response. (Table 1) Response to $\mathrm{RT}$ ranged from $50 \%$ to $80.6 \%$. The median duration of response ranged from 1.5 to 11.4 months. Symptom response to palliative RT is seen in table 2 .

Only 122 patients were eligible for subgroup analyses as BED data were available. The overall pooled response rate for bleeding is $74 \%\left(95 \%\right.$ CI $0.64-0.85 . \mathrm{I}^{2}=$ $68 \%$ ) (Figure 2-1). There was no difference in response rate of bleeding between regimens with biological equivalent dose (BED) of $\geq 39 \mathrm{~Gy}$ versus regimens with $\mathrm{BED}<39 \mathrm{~Gy}$ (relative risk 1.53, 95\%CI 1.20-1.95; p value $=0.39$ ) (Figure 2-4). Two studies suggested that local control was inferior for patients treated with BED regimens of $<41 \mathrm{~Gy}$. [6, 15]

\section{Pain}

Two studies included a total of 18 patients who presented with pain. $[6,15]$ One study defined response as patient not requiring interventions such as neurolysis on follow-up. [6] The other study used a 3 point scale to grade symptom response. [15] Response rates for pain ranged from $45.5 \%$ to $86 \%$ (Table 2 ). Median duration of response for pain was 7.8 months reported in one study. [15] The overall pooled response rate for pain is $67 \%$ (95\% CI $0.36-1.23 . \mathrm{I}^{2}=66 \%$ ) (Figure $\left.2-2\right)$.

\section{Obstruction}

Two studies included a total of 33 patients who presented with obstruction.[6, 15] One study defined response as patient not requiring interventions such as stenting on follow-up.[6 ] The other study used a 3 point scale to grade symptom response.[15] Response rates for obstruction ranged from $51.2 \%$ to $81 \%$ (Table 2). Median duration of response for obstruction ranged from 3.2 to 6.2 months. The overall pooled response rate for obstruction is 68\% (95\% CI 0.45-1.03. I²=64\%). (Figure 2-3)

\section{Toxicity}

An overview of the toxicities reported in all studies is presented in table 3. One study did not report toxicity outcomes.[5] Validated grading scales such as Radiation Therapy Oncology Group (RTOG) or Common Toxicity Criteria (CTC) scales were used. Chemoradiotherapy was associated with increased toxicities. Grade 3 to 4 acute 
toxicities occurred in up to $15 \%$ of patients for patients treated with RT alone and up to $25 \%$ of patients treated with chemoradiotherapy. One study reported late grade 3 Gastrointestinal hemorrhage in $8 \%(1 / 12)$ patients who underwent chemoradiotherapy.

\section{DISCUSSION}

To the best of our knowledge, this is the first systematic review that summarized quantitatively the results of studies with different dose fractionation schedules of palliative gastric RT for locally advanced GC. Despite a comprehensive literature search, we found only seven relevant studies reporting outcomes of palliative RT for GC. We did not find any prospective studies that complied with our search criteria. Our review showed that RT for localised GC symptoms had high response rates, with pooled overall response rates for bleeding, pain and obstruction symptoms were $74 \%, 67 \%$ and $68 \%$ respectively. This is consistent with palliative RT for other organ sites.[17, 18]
Whilst chemotherapy can improve the survival for patients with advanced disease, it may be inadequate for the palliation of local symptoms. RT alone can provide adequate palliation without the morbidity of chemotherapy. In addition, it may be the only option for elderly patients not fit for chemotherapy, patients with poor performance status, or patients who have progressed on chemotherapy.

Although there was significant heterogeneity in the dose fractionation regimens used (ranging from $8 \mathrm{~Gy}$ to $50 \mathrm{~Gy}$ in 1.8 to $8 \mathrm{~Gy}$ per fraction), the pooled overall response rate of $\geq 67 \%$ suggests that $\mathrm{RT}$ is effective in palliating localised gastric bleeding/pain and obstruction. Pooled response for bleeding according to BED showed that there was no difference in response rates between regimens with $\mathrm{BED}$ of $\geq 39 \mathrm{~Gy}$ versus regimens with $\mathrm{BED}<39 \mathrm{~Gy}$. Lack of a dose response relationship has also been demonstrated for palliative RT for other cancers. The Medical Research Council BA09 trial compared 2 hypofractionated regimens of RT in the palliation of muscle invasive bladder cancer, and concluded that

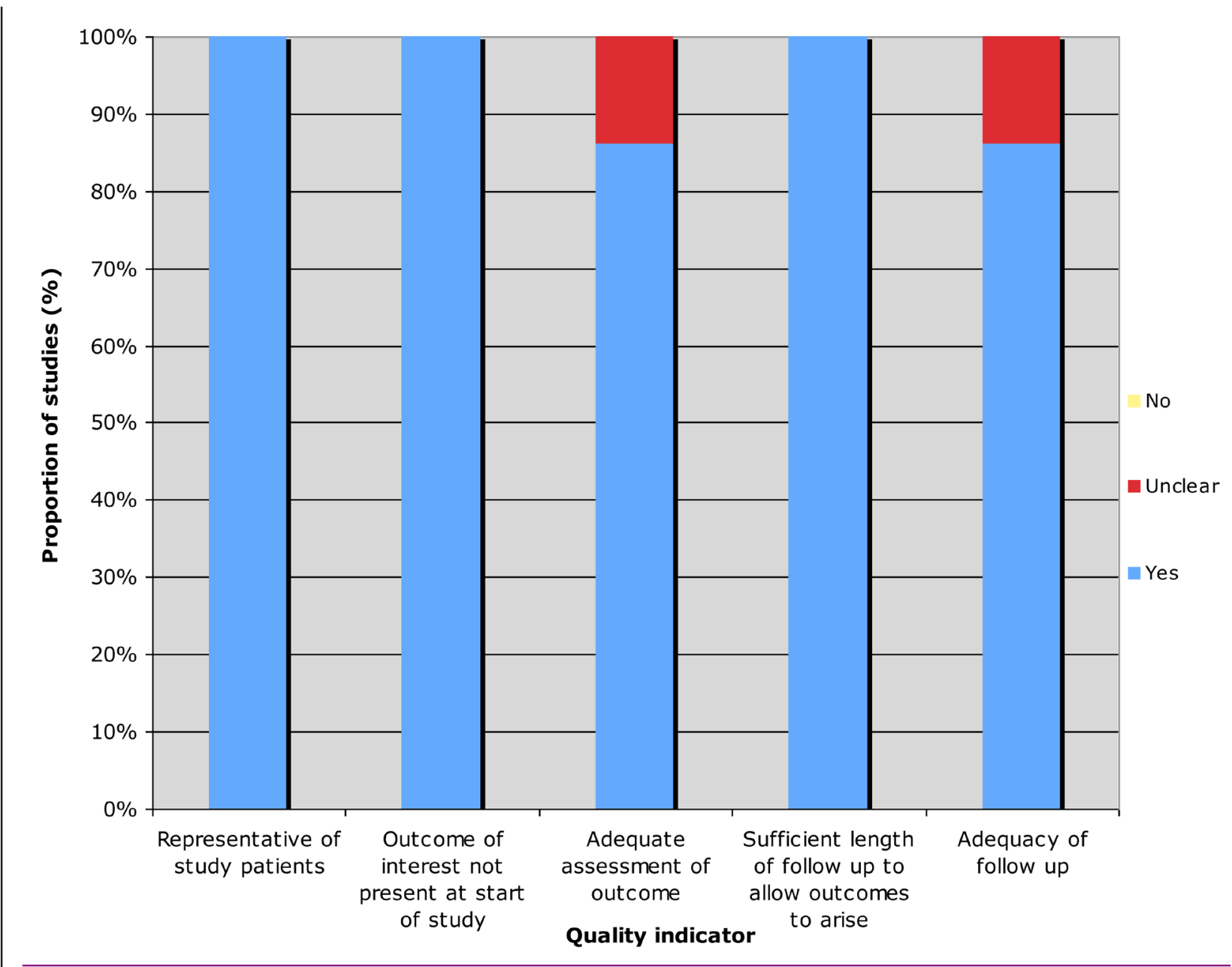

Figure 3: Assessment of quality of included studies. 
the $21 \mathrm{~Gy} / 3$ fraction regimen (low BED) appeared to be as effective as the $35 \mathrm{~Gy} / 10$ fraction regimen (high BED) [18] In a systematic review of palliative thoracic RT for lung cancer, Fairchild et al also demonstrated that using a cut-off $\operatorname{BED}$ of $35 \mathrm{~Gy}(\alpha / \beta=10)$, there was no difference in palliation of hemoptysis, chest pain and cough between high dose $(\geq 35 \mathrm{~Gy})$ vs. low dose $(<35 \mathrm{~Gy})$ regimens.[17] These results, together with the results from our study suggest low BED regimens may be equally efficacious at symptom palliation compared to higher BED regimen. Short fractionation (low BED) regimens may be more desirable and preferred in patients with limited life expectancy, poor functional status, and who need to receive early systemic treatment for rapidly progressing systemic disease. In addition to symptom response, duration of palliation is an important endpoint for palliative treatments. Duration of symptom palliation was not reported in 3 of the 7 included studies. Two studies suggested that duration of palliation was inferior for RT regimens with BED of $\leq 41 \mathrm{~Gy}$, highlighting that prospective trials are needed to determine the optimal dose fractionation regimens for patients.

Validated grading scales such as RTOG or CTC were used in the studies for toxicity assessment. However, in retrospective studies, reviews of toxicity rates and duration cannot be accurately estimated. The absence of patient reported outcomes (PROs), such as quality of life assessments may make toxicity from treatment difficult to interpret. Nausea during or after treatment for example, may be due to various factors such as increasing doses of analgesia, tumour progression or may be treatment related. Validated questionnaires such as the European Organisation for Research and Treatment of Cancer (EORTC) Quality of life questionnaire C30 or the EORTC gastric cancer module should be used for PRO reporting.

Twenty percent of patients were treated with chemoradiotherapy. The results show that chemoradiotherapy is associated with increased toxicities with uncertain benefit on symptom palliation. With the exception of one study[16], symptom response was not reported according to whether the patient received RT alone or chemoradiotherapy. Toxicities appear to be acceptable for patients treated with RT alone. Grade 3 to 4 acute toxicities occurred in up to $15 \%$ of patients for patients treated with RT alone and up to $25 \%$ of patients treated with chemoradiotherapy. One study reported late grade 3 Gastrointestinal hemorrhage in $8 \%$ (1/12) patients who underwent chemoradiotherapy.[14] Indeed, the TROG 03.01,NCIC CTG ES2 randomised trial showed that palliation of dysphagia for patients with advanced esophageal cancer was not siginificantly improved with the addition of cisplatin/ 5 flurouracil chemotherapy to RT, but was associated with increased toxicity.[19] Further research is required to define the role of chemoradiotherapy in palliating localized gastric symptoms.
Whilst this review showed a benefit for palliative RT for localised GC symptoms, the reviewers also acknowledge that the included studies had several limitations. Firstly, a wide range of dose fractionation regimens were used with varying definitions of response to RT for bleeding, pain and obstruction, as well as time points for assessment of treatment response. This precludes the conclusions of dose response or most appropriate dose fractionation regimens. Secondly, twenty percent of patients were treated with chemoradiotherapy, which may influence response rates and treatment toxicity. Thirdly, no study reported PROs, which are important in the measures of effects of palliative treatment and should now be routinely included in studies of palliative interventions. Lastly, retrospective studies are at risk of reviewer bias, leading to overestimation of treatment effect or underestimation of treatment toxicities.

\section{CONCLUSIONS}

This review suggests that two-thirds of patients receiving RT will experience a clinical benefit, with the highest response rate for haemostasis. Low BED regimens appear to be adequate for symptom palliation. Toxicity rates appear acceptable for patients treated with RT alone but are significanty increased with chemoradiotherapy.

The optimal dose fractionation regimen for symptom palliation is unclear. Prospective studies to determine the effects of palliative RT in inoperable gastric cancer on HRQL outcomes are warranted.

\section{MATERIALS AND METHODS}

\section{Search strategy}

Searches of the Medline and Central library databases were performed up till December 2015. The following MESH terms were used in the search strategy: Stomach neoplasm, radiotherapy, and palliative care. Results were screened by two authors. Full text copies of studies were obtained. Additional studies were identified from the reference lists of the articles reviewed in full text.

\section{Eligibility}

We included studies of palliative gastric RT for patients with GC. Studies that reported symptom response (bleeding, pain, obstruction), toxicity or quality of life were included. We included retrospective reviews and non randomized studies. Case reports were excluded. Studies that included patients treated with RT as a subgroup was included as long as outcome of palliative RT for the subgroup was reported. 


\section{Evaluation of studies}

We adopted the Newcastle-Ottawa quality assessment scale for assessment of quality as we included non-comparative studies in our systematic review. [7] We selected items that were evaluated if: (1) The study patients were representative of the population of interest, (2) the outcome of interest was demonstrated to be absent at the start of the study, (3) there was adequate assessment of outcome, (4) there was sufficient length of follow up to allow outcomes to arise, and (5) there was adequacy of follow up (i.e. all patients in the study were accounted for) (Figure 3). Potential articles were evaluated by two authors and differences were resolved consensually.

Treatment parameters collected included RT planning (CT planned vs 2D planned), organ at risk dose constraints, RT dose fractionation regimen, RT technique. Outcomes of interest included symptom response according the the authors' definition, duration of palliation, median survival, BED calculation and correlation, quality of life, acute and late treatment toxicities.

\section{Statistical analysis}

We calculated event rates of outcome i.e. the proportion of patients who developed outcomes of interest from the included cohorts and estimated the $95 \%$ confidence interval with the Jeffreys method.[8] We combined the individual log-transformed event rates and their variances using the generic inverse variance method. The meta-analysis was performed using the Cochrane Collaboration software (RevMan version 5.2; http:// www. cochrane.org). Primary analyses were done with Der Simonian and Laird random effects model.[9] Statistical heterogeneity of the combined results was assessed by the I2 statistic.[10] An $\mathrm{I}^{2}$ value of lower than $25 \%$ was interpreted as signifying a low level of heterogeneity. We used the Altman's test of interaction to compare the logtransformed rates of outcomes between the three treatment strategies.[11]

\section{Subgroup analysis}

Subgroup analyses were performed to determine if the results were influenced by the BED. To analyse for a dose response relationship for patients who presented with bleeding, we used the cut-off BED of $39 \mathrm{~Gy}$, corresponding to the most commonly prescribed dose fractionation regimen of $30 \mathrm{~Gy}$ in 10 fractions.

The BED is an approximate quantity by which different RT fractionation regimens are compared. It is given by $\mathrm{BED}=\mathrm{nD}(1+[\mathrm{D} /\{\alpha / \beta\}])$, where $\mathrm{n}=$ number of fractions, $\mathrm{D}=$ dose/fraction, $\mathrm{nD}=$ total dose, and $\alpha / \beta$ is the alpha/beta ratio, and is taken to be 10 for adenocarcinomas.

\section{CONFLICTS OF INTEREST}

The authors declare no conflicts of interest.

\section{REFERENCES}

1. Mantell BS. Radiotherapy for dysphagia due to gastric carcinoma. Br J Surg. 1982; 69:69-70.

2. Myint AS. The role of radiotherapy in the palliative treatment of gastrointestinal cancer. Eur J Gastroenterol Hepatol. 2000; 12:381-90.

3. Tsukiyama I, Akine Y, Kajiura Y, Ogino T, Yamashita K, Egawa S, Hijikata J, Kitagawa T. Radiation therapy for advanced gastric cancer. Int J Radiat Oncol Biol Phys. $1988 ; 15: 123-27$.

4. Nordman E. Value of megavolt therapy in gastric carcinoma. Bull Cancer. 1976; 63:217-22.

5. Chaw CL, Niblock PG, Chaw CS, Adamson DJ. The role of palliative radiotherapy for haemostasis in unresectable gastric cancer: a single-institution experience. Ecancermedicalscience. 2014; 8:384.

6. Kim MM, Rana V, Janjan NA, Das P, Phan AT, Delclos ME, Mansfield PF, Ajani JA, Crane CH, Krishnan S. Clinical benefit of palliative radiation therapy in advanced gastric cancer. Acta Oncol. 2008; 47:421-27.

7. Wells GA, Shea B, O'Connell D. The Newcastle-Ottawa Scale for assessing the quality of non-randomized studies in meta-analyses. 2014. http://www.ohri.ca/programs/clinical_ epidemiology/oxford.asp.

8. Brown LD, Cat TT, DasGupta A. Interval estimation for a proportion. Stat Sci. 2001; 16:101-33.

9. DerSimonian R, Laird N. Meta-analysis in clinical trials. Control Clin Trials. 1986; 7:177-88.

10. Higgins JP, Thompson SG, Deeks JJ, Altman DG. Measuring inconsistency in meta-analyses. BMJ. 2003; 327:557-60.

11. Altman DG, Bland JM. Interaction revisited: the difference between two estimates. BMJ. 2003; 326:219.

12. Hashimoto K, Mayahara H, Takashima A, Nakajima TE, Kato K, Hamaguchi T, Ito Y, Yamada Y, Kagami Y, Itami J, Shimada Y. Palliative radiation therapy for hemorrhage of unresectable gastric cancer: a single institute experience. J Cancer Res Clin Oncol. 2009; 135:1117-23.

13. Lee JA, Lim DH, Park W, Ahn YC, Huh SJ. Radiation therapy for gastric cancer bleeding. Tumori. 2009; 95:72630.

14. Asakura H, Hashimoto T, Harada H, Mizumoto M, Furutani K, Hasuike N, Matsuoka M, Ono H, Boku N, Nishimura T. Palliative radiotherapy for bleeding from advanced gastric cancer: is a schedule of 30 Gy in 10 fractions adequate? J Cancer Res Clin Oncol. 2011; 137:125-30.

15. Tey J, Choo BA, Leong CN, Loy EY, Wong LC, Lim K, Lu JJ, Koh WY. Clinical outcome of palliative radiotherapy for locally advanced symptomatic gastric cancer in the modern 
era. Medicine (Baltimore). 2014; 93:e118.

16. Kondoh C, Shitara K, Nomura M, Takahari D, Ura T, Tachibana H, Tomita N, Kodaira T, Muro K. Efficacy of palliative radiotherapy for gastric bleeding in patients with unresectable advanced gastric cancer: a retrospective cohort study. BMC Palliat Care. 2015; 14:37.

17. Fairchild A, Harris K, Barnes E, Wong R, Lutz S, Bezjak A, Cheung $\mathrm{P}$, Chow E. Palliative thoracic radiotherapy for lung cancer: a systematic review. J Clin Oncol. 2008; 26:400111.

18. Duchesne GM, Bolger JJ, Griffiths GO, Trevor Roberts J, Graham JD, Hoskin PJ, Fossâ SD, Uscinska BM, Parmar MK. A randomized trial of hypofractionated schedules of palliative radiotherapy in the management of bladder carcinoma: results of medical research council trial BA09. Int J Radiat Oncol Biol Phys. 2000; 47:379-88.
19. Penniment MG, Harvey JA, Wong R, Stephens S, Au H, O'Callaghan CJ, Kneebone AB, Ngan S, Ward IG, Roy R, Sullivan T, Nijjar T, Biagi J, et al. Best Practice in Advanced Esophageal Cancer: A Report on Trans-Tasman Radiation Oncology Group TROG 03.01 and NCIC CTG ES.2 Multinational Phase 3 Study in Advanced Esophageal Cancer (OC) Comparing Quality of Life (QOL) and Palliation of Dysphagia in Patients Treated With Radiation Therapy (RT) or Chemoradiation Therapy (CRT). Int J Radiat Oncol Biol Phys. 2014; 90:S3. 